\title{
Ontogeny of the oestrogen receptors ESR1 and ESR2 during gonadal development in the tammar wallaby, Macropus eugenii
}

\author{
Natalie E Calatayud, Andrew J Pask, Geoffrey Shaw, Nadine M Richings, \\ Sue Osborn and Marilyn B Renfree \\ Department of Zoology, The University of Melbourne, Melbourne, Victoria 3010, Australia \\ Correspondence should be addressed to N E Calatayud; Email: nec@unimelb.edu.au \\ A J Pask is now at Department of Molecular and Cellular Biology, University of Connecticut, Storrs, Connecticut 06269, USA \\ N M Richings is now at Melbourne IVF 10/320 Victoria Parade, East Melbourne, Victoria 3002, Australia
}

\begin{abstract}
Oestrogen has wide ranging effects in development mediated mainly via the two oestrogen receptors, $\alpha$ (ESR1, also known as ER $\alpha)$ and $\beta$ (ESR2, also known as ERß). Oestrogen is the key factor that directs the indifferent gonad to become an ovary in many non-mammalian vertebrates. Oestrogen is not required for early ovarian differentiation in mammals but can disrupt normal testicular development in eutherians. Surprisingly, exogenous oestrogen can cause sex reversal of an XY gonad in two marsupials, the North American opossum and the tammar wallaby. To understand the mechanism by which oestrogen induces sex reversal, we characterised the genes for ESR1 and ESR2 and examined their expression during gonadal differentiation in the tammar wallaby, Macropus eugenii. Both receptors were expressed in the somatic cells and germ cells of the indifferent gonad in both XX and XY foetuses throughout all stages of development, and persisted in these cells into adulthood. ERs were also present in many other tissues including kidney, pituitary and mammary gland. ER mRNA was not significantly altered by exogenous oestrogen in cultured $X Y$ gonads but the receptors translocated to the nucleus in its presence. These findings confirm that there is conserved expression of the ERs in the indifferent gonad despite the lack of available ligand during early gonadal development. The receptors can respond to exogenous estrogen at this early stage and are capable of transducing signals in the early mammalian gonad. However, the selective forces that maintained conserved ER expression in this tissue remain unknown.
\end{abstract}

Reproduction (2010) 139 599-611

\section{Introduction}

Oestrogen receptors (ERs) are members of the nuclear hormone receptor superfamily, contain six functional domains, regions A-F (Kumar et al. 1987), and are highly conserved among the vertebrates (Couse \& Korach 1999). ERs form homo- and heterodimers and, once activated, these can bind directly to oestrogen response elements (EREs) in target genes to mediate transcription of multiple developmental and homeostatic pathways (Pace et al. 1997, Pettersson et al. 1997, Lindberg et al. 2003). While the primary function of the ERs is as direct transcription factors, they can also indirectly affect gene transcription. When activated by oestrogen, outer cell membrane-bound ERs increase $\mathrm{Ca}^{2+}$ and nitric oxide, and signal transduction occurs via MAP kinase pathway (Bjornstrom \& Sjobergp 2005, Levin 2005). There are three possible 'non-classical' ER pathways: ligand-independent signaling, non-genotrophic effects via a membrane-associated ER and genotrophic EREindependent signaling via protein-protein interactions with other transcription factors (McDevitt et al. 2008).
In mice lacking either ESR1 (also known as ER $\alpha$ ) or ESR2 (also known as ER $\beta$ ) or both receptors (double knockout), there is surprisingly little impact on early gonadal development (Couse et al. 1995, Korach et al. 1996, Dixon et al. 1997, Krege et al. 1998, Dupont et al. 2000). The ESR1 ( $\alpha$ ERKO) and double ESR1/ESR2 $(\alpha \beta E R K O)$ knockouts have the greatest morphological and behavioural abnormalities (Lubahn et al. 1993, Couse et al. 1995, 2001, Eddy et al. 1996, Dixon et al. 1997, Krege et al. 1998, Rosenfeld et al. 1998, Couse \& Korach 1999, Dupont et al. 2000). While early gonadal differentiation appears normal in both female and male mice, reproduction is compromised later in development through a loss of the normal hypothalamicpituitary-gonadal axis feedback loop (Dupont et al. 2000). Targeted disruption of ESR1 results in infertility, while loss of ESR2 causes a later, age-related infertility in females (Couse et al. 2000). The phenotype observed in the $\alpha \beta E R K O$ female suggests that loss of oestrogen stimulation and its receptor action result in ovarian transdifferentiation and expression of testicular genes, similar to the phenotype of the aromatase knockout 
(ARKO) mouse (Fisher et al. 1998, Couse \& Korach 1999). Oestrogen administration to the ARKO mouse with transdifferentiated ovaries restores ovarian function and the normal expression of ovarian markers. Both oestrogen and ERs are required to direct and maintain the fate of supporting cells in the gonad, but are not required for their initial specification and differentiation (Couse \& Korach 1999, Britt \& Findlay 2003, Dupont et al. 2003, Britt et al. 2004). This is in contrast to the role of oestrogen in birds, reptiles, amphibians and fish in which it is essential in maintaining not only reproductive function but also for sex determination (Mak et al. 1983, Pieau et al. 1998, Miyashita et al. 2000, Pieau \& Dorizzi 2004, Katsu et al. 2006, Gist et al. 2007).

How and why oestrogen became dissociated from sex determination in mammals is unknown. One hypothesis suggests that the development of mammalian (therian) foetuses in utero necessitated the change from a hormonal to a genetic sex-determining switch (the $S R Y$ gene on the Y-chromosome) to afford male foetuses protection against the feminising effects of maternal oestrogen (Mittwoch 1993). However, exogenous oestrogen can cause gonadal sex reversal and ovarian development in a male marsupial young if administered before gonadal differentiation (Burns 1956, 1961, Coveney et al. 2001), suggesting that SRY offers the foetus no such protection. Furthermore, ERs are expressed in the foetal gonads of mice and humans despite their apparent redundancy at this time, thereby providing a mechanism through which oestrogen could exert its effects if it were present (Greco et al. 1992, 1993, Hou \& Gorski 1993, Hou et al. 1996).

In this study, we report the first comparative study of ERs in a non-eutherian mammal, the marsupial tammar wallaby, Macropus eugenii. Marsupials are therian mammals that diverged from eutherian mammals around 148 million years ago (Bininda-Emonds et al. 2007). The tammar is a useful model to examine the role of oestrogen and its receptors in foetal development as the majority of sexual differentiation occurs post partum (pp) where the young are accessible in the pouch for experimental manipulation (Renfree et al. 1992, 1996). The indifferent gonad first forms around day 21 of the 26.5-day gestation, but the first signs of sexual differentiation do not occur in males until the appearance of the testicular cords around day 2 pp. In females, histological differentiation of the ovary is not apparent until around day $8 \mathrm{pp}$ (Renfree et al. 1996). Treatment of tammar wallaby young with exogenous oestrogen from the day of birth for 25 days leads to disrupted testicular development (Shaw et al. 1988). However, similar treatment of premature young (born on day 25 of gestation) with exogenous oestrogen induces complete XY gonadal sex reversal (Burns 1961, Coveney et al. 2001, Renfree et al. 2001a). Since the effects of oestrogen are almost entirely mediated through the ERs in the gonad (Couse \& Korach 1999), we sought to characterise the expression of the ERs in the developing tammar wallaby gonad to see if they are present and capable of transducing oestrogen signals during sex reversal. Oestrogen and progesterone receptors have been measured in the female genital tract during pregnancy in adult females (Renfree \& Blanden 2000), but nothing is known of ER expression in the gonads during early development or in adult tissues. We therefore examined the ontogeny of expression of ESR1 and ESR2 in the tammar wallaby gonad throughout normal development and during oestrogen exposure.

\section{Results}

\section{Molecular characterisation of tammar ESR1 (tESR1) and tammar ESR2 (tESR2) in male and female gonads and adult somatic tissues}

\section{Cloning}

tESR 1 and $t E S R 2$ cDNA was partially cloned by PCR using cross-species primers designed to regions conserved between cow, cat, human, horse, mouse, rat, grey shorttailed opossum, alligator and chicken (Table 1). The full-length cDNA was derived from PCR fragments and the tammar wallaby genome trace archives (www.ensembl. org). $t E S R 1$ and $t E S R 2$ were highly conserved with orthologues from an array of vertebrate species (Table 2).

\section{tESR1 and tESR2 sequence comparison}

tESR1 and tESR2 produced a predicted protein of comparable size to human and other vertebrate species. The greatest size difference was seen in the ligand-binding domain, which is (233aa) 14 amino acids larger in the tammar, and in the $\mathrm{F}$ domain, which is 18 amino acids smaller in the tammar. In contrast, tESR1 had both a

Table 1 Cross species primers designed to regions conserved across cow, cat, human, horse, mouse, rat, grey short-tailed opossum, alligator and chicken.

\begin{tabular}{ll}
\hline Primer name & Sequence $\mathbf{5}^{\prime} \mathbf{-} \mathbf{3}^{\prime}$ \\
\hline ESR1 & \\
$1447 \mathrm{Fw}$ & ATG ATC AAC TGG GCR(A) AAG AG \\
$1924 \mathrm{Rv}$ & CAC ATG ATG AAC AAA GGC AT \\
$383 \mathrm{Fw}$ & GTG CCC TAC TAC CTG GAG AA \\
$950 R v$ & CTC AGC ATC CAA CAA GGC AC \\
ERS4Fw & AAG CAT TCA AGG GCA TAA CGA \\
ERS4Rv & ATC TCT TTG GCG TTT ATG TTT \\
ERS3Fw & CAG GGT GGT AGA GAA AGA TTG \\
ERS3Rv & TCG TTA TGC CCT TGA ATG GTT \\
ER1S2Fw & TGC CCT ATT ACT TGG AAA ATG AG \\
ERS2Rv & CAA TCT TTC TCT ACC ACC CTG \\
ESR2 & \\
ESRB1FW & TTC CAG TAT GTT CCC TTT AGC AGC \\
ESRB1RV & GAT TCC ACT CTT TGC GAT AAC \\
ESRB2RV & AGA AGC ATC AGA AGG TTA GCG \\
ERB969RV & GAC ATC ATC ATG GAG GCC TC \\
ERB589FW & GGT CRT GTG AAG GAT GTA AG \\
\hline
\end{tabular}


Table 2 Sequence homologies of $t E S R 1$ and $t E S R 2$ of the tammar and selected species for which alignments were performed (see Fig. 3). Sequence homologies indicate a high degree of conservation of the $t E S R 1$ sequence with both mammalian and non-mammalian vertebrates. There was a high degree of conservation of the tESR2 sequence with other mammals and with the chicken.

\begin{tabular}{lcc}
\hline Species & Accession number & $\begin{array}{c}\text { Percentage } \\
\text { homology (\%) }\end{array}$ \\
\hline ESR1 & NM001001443 & 68 \\
Bos taurus & NM001081772 & 85 \\
Eqqus caballus & NM001024231 & 79 \\
Felis catus & NM000125 & 79 \\
Homo sapiens & NM007956 & 77 \\
Mus musculus & XM001370990 & 94 \\
Monodelphis domestica & AB115909 & 84 \\
Alligator mississippiensis & NM205183 & 83 \\
Gallus gallus & & \\
ESR2 & AY785359, BC02418 & 81 \\
Bos taurus & AD24432 & 79 \\
Homo sapiens & NM_010157 & 81 \\
Mus musculus & ENSMOD- & 94 \\
Monodelphis domestica & T00000011756 & \\
Rattus norvegicus & NM_012754 & 80 \\
Gallus gallus & NM_204794 & 81 \\
\hline
\end{tabular}

smaller ligand-binding domain and $\mathrm{F}$ domain than hESR2 (Fig. 1a). Conservation is greatest between ESR1 and ESR2 in the $\mathrm{C}$ domain (DNA-binding) which is responsible for the specific recognition of the EREs within the target genes. The $A / B$ domain was the least conserved region between the tERs and compared to other species (Fig. 1b).

\section{tESR1 and tESR2 $m R$ NA expression in the gonad}

$t E S R 1$ and $t E S R 2$ mRNAs were expressed in gonads from day 24 of gestation, before the onset of gonadal differentiation in the $X Y$ gonad, (around 3 days later) through to adulthood in both males and females (Fig. 2).

\section{Northern blot}

ESR1 $(1.9 \mathrm{~kb})$ and ESR2 (1.3 kb) transcripts were detected by northern analysis using a radiolabelled probe. ESR 1 and ESR2 were detected in ovary, testis, kidney, adrenal, liver, pituitary, hypothalamus and mammary gland tissue (at days 80, 150 and 280 of lactation), with the greatest expression detected in the kidney (Fig. 3).

\section{Western blotting}

Western immunoblotting was used to verify the specificity of the (Ab-16 ESR1 and Ab-24 tESR2; Neomarkers, Fremont, CA, USA) antibodies used to determine tESR1 and tESR2 protein staining in the tammar. A single band was observed at $\sim 70 \mathrm{kDa}$ for the tESR1 ovary protein extract, and a single band was observed for tESR2 in the tammar western blot at $\sim 57 \mathrm{kDa}$. In the rabbit ovary positive control, two bands were detected for rabbit ESR1 at $\sim 70 \mathrm{kDa}$ and another band between 72 and $80 \mathrm{kDa}$ in the rabbit positive control. No bands were detected in the BSA negative control lane, in the presence of antibody indicating specific binding to the rabbit and wallaby proteins (Fig. 4).

\section{Immunohistochemistry}

tESR1 and tESR2 receptor proteins were detected in the tammar wallaby ovary and testis before sexual differentiation, during development and in the adult. There was no sexual dimorphism in the level or distribution of the ERs prior to sexual differentiation. Both receptors were detected in the cytoplasm of supporting cells (i.e. granulosa, theca, Sertoli and Leydig) of male and female gametes until the first signs of male differentiation at day 2 of pouch life (pp) as well as in the cytoplasm and nucleus of germ cells.

In males from day 2 of pouch life, both ERs were observed in the developing seminiferous tubules indicating that protein was mainly confined to the Sertoli and germ cells. Seminiferous tubules were intensely stained in all stages tested indicating that the protein was present throughout development, especially in the cytoplasm of Sertoli cells (Fig. $5 \mathrm{j}$ and $\mathrm{k}$ ). The surrounding stromal tissue was negative for ER staining. Staining of the Leydig cells was largely cytoplasmic but became more intense and nuclear as development progressed (Fig. 6f).

In the adult testis, tESR1 staining was detected at various stages of spermatogenesis. There was no tESR1 immunoreactivity in primary spermatocytes in pachytene, but the cytoplasm of round spermatids was lightly stained and there was little or no nuclear staining (Fig. 6e and $\mathrm{f}$ ). The strongest staining occurred in the cytoplasm of round spermatids while elongating spermatids showed medium to strong staining (Fig. 6e and f). The peritubular myoid cells surrounding the cords were not immunoreactive for tESR1 (Fig. 6e and f). In the adult testis, the cytoplasm and nucleus of Sertoli and Leydig cells as well as spermatogonia were immunopositive for both ERs (Fig. 6e and f, Table 3).

In females, ER staining was strong in the early developing ovary, mainly in the cortex and localised to the germ cells. Staining was weak or absent from the interstitial tissue of the developing ovary (Fig. 5a, b, d and e). At day $67(\mathrm{a}-\mathrm{c})$, staining was localised to the germ cells that had aggregated into nests in the cortex and showed both a cytoplasmic and a nuclear distribution. By day 110 , the germ cells had organised into primordial follicles surrounded by granulosa cells (Fig. $5 d-f$ ), and ERs were localised to the cytoplasm of the developing oocytes (Fig. $5 \mathrm{~d}$ and e).

In the adult, both receptors were found in the interstitial tissue at all stages of follicle development and in the surface epithelium (Fig. 6a and b). 
(a)

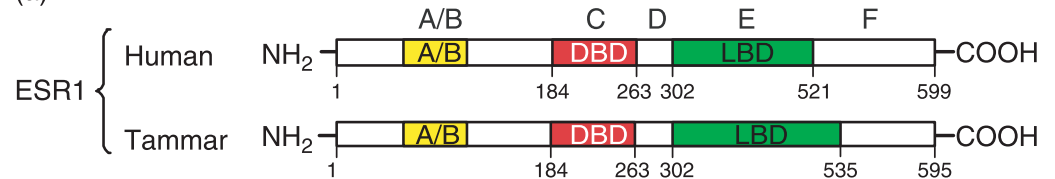

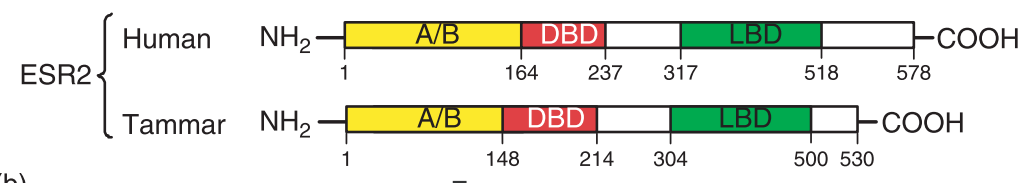

(b)

$$
\mathrm{F}
$$

ESR2 Tammar EHSPLYIPSS VEGCHEYS A MAFỸSPTVMN YS--IPSNAN DSEG-GAVRESR1 Tammar NKTGVYSYPE GAAYDFNTA APVYGSSNLT YAPNSETSAF SSNGL GFHS

ESR2 Tammar -QTTSPN--I LWPTPGHLSP IT-LHCQSSL LYAAE-PQKGP WCEARAVEHV ESR1 Tammar LNNVSPNPLV LLHPETQLSP FLHHHSQQVP YYLENEQSG - YAMSEAAPQA

ESR2 Tammar L---PG-NIKE RLKRKVNGNS CNSPI INXPG SKRDAHFCAV CSDYASGYHY ESR1 Tammar FYRPPSDNRR QNARERLASA GDKGNLAMES AK-ETRYCAV CNDYASGYHY

ESR2 Tammar GVWSCEGCKA FFKRSIQGHN DYICPATNQC TIDKNRRKSC QACRLRKCYE ESR1 Tammar GVWSCEGCKA FFKRSIQGHN DYMCPATNQC TIDKNRRKSC QACRLRKCYE

ESR2 Tammar VGMMKCGSRR EPCGYRVIR- -RQRNADEQX XCLSKAKKNS ENVTRVKELI

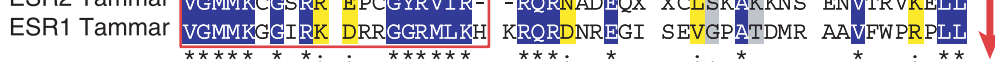

ESR2 Tammar MN- - - - . - - AMSPEQFVL SFLEAEPPNV FVS-RPSKPF TEASMMMSLT ESR1 Tammar INRSRTNSLS LSTTSHPMVD GLWDGQLPLM NPGFQLIEPL GKASSMAHTR ESR2 Tammar KLADKELVHM IGWAKKIPGF VELSLYDQVR LLESCWMMEVI MVGLMWRSID

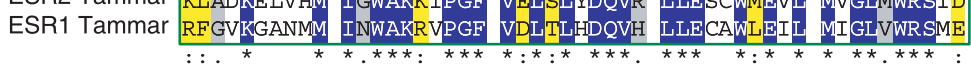
ESR2 Tammar HPGKLIFAPD LVLDRDEGKC VEGILEIFDM LLATTSRFRE LKLQHKEYLC

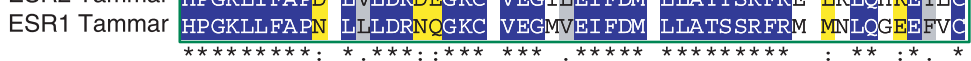
ESR2 Tammar VKAMILLNSS MFPLATATEE P-ESSRKLHH LINAVTDALV WVIAKSGISS

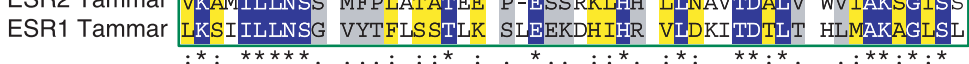
ESR2 Tammar QQQS IRLANL LMLLSHVRHA SNKGMEHLLS MKCKNVVPVY DLLLEMLNAH

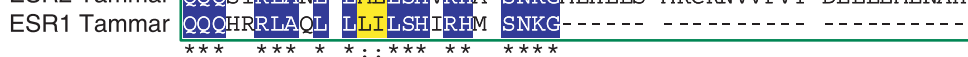
ESR2 Tammar TLRGYKKSSV SVSEYGPAEQ SESKERSPQD LLPQ ESR1 Tammar
Figure 1 (a) Diagrammatic representation of the functional domains of human oestrogen receptor alpha (hESR1) compared to that of the tammar. hESR1 is comprised of 599 amino acids (indicated at top) and is organised into six functional domains (A-F). The tammar ESR1 also contains six domains and 595 amino acids. In the human, the $\mathrm{A} / \mathrm{B}$ region is important for transactivation and gene specificity, $C$ is the DNA-binding domain (DBD), $\mathrm{D}$ is the hinge region, which allows the protein to undergo conformational changes, E contains the ligand-binding domain (LBD), and $\mathrm{F}$ is thought to play a role in distinguishing between agonist and antagonist binding in hESR1 molecule (for a more detailed review of domain functions see Couse \& Korach 1999). Full-length hESR2 contains 578 amino acids and the tammar 530 amino acids (indicated at top) and has similar functional domain structure (A-F) as hESR1. Region C (DBD) is highly homologous between hESR2 and hESR1 ( 96\%). Figure adapted from Pavao \& Traish (2001). (b) Partial amino acid comparison of tammar ESR1 and ESR2 as determined by ClustalW (Chenna et al. 2003). Conserved amino acids are highlighted in blue and underlined by an asterisk $(*)$, and highly similar amino acids are shown in yellow and underlined by a colon (:), while similar amino acids are indicated by a full stop (.). The highest degree of conservation was found in the $\mathrm{C}$ domain (DNA-binding domain; red box, red arrow), which is responsible for the specific recognition of the oestrogen response elements (EREs) within target genes. The ligandbinding domain was also highly conserved (shown by green box, green arrow).
Both ERs were detected in the cytoplasm and nucleus of oocytes at all stages of follicle development (Fig. 6a-d). The granulosa cells of all follicles had predominantly cytoplasmic staining. Both ERs were cytoplasmic in the theca cells (Fig. 6a-d, Table 3).

\section{Effect of exogenous oestrogen exposure}

\section{Protein distribution}

In XY gonads cultured without oestrogen (control; Fig. $7 \mathrm{a}-\mathrm{C})$, the ERs were primarily cytoplasmic and confined to the seminiferous tubules and surface epithelium, and staining was absent in the interstitial tissue. In the $X Y$ gonads cultured with oestrogen (Fig. $7 \mathrm{~d}-\mathrm{f}$ ), both ERs became predominantly nuclear and seminiferous cords failed to form as previously described (Coveney et al. 2001).

\section{Quantitative tESR1 and tESR2 real-time expression in the $X Y$ oestrogen-cultured gonad}

Quantitative of $X Y$ gonads cultured with oestrogen from day 25 of gestation confirmed expression of tESR 1 and tESR2 in all samples tested, but there was no significant 


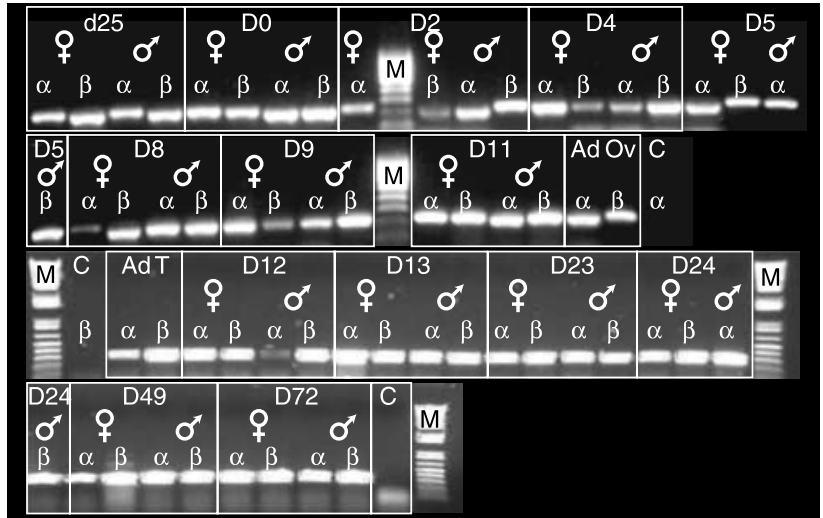

Figure 2 RT-PCR of ESR1 $(\alpha)$ and ESR2 ( $\beta$ ) in the developing and adult tammar wallaby gonads. Expression of both receptors was detected at every stage examined from day 25 of gestation through to adult ovary (Ad Ov) and testis (Ad T). The age of the gonad is shown at the top with $\mathrm{d}$ denoting day of gestation and $\mathrm{D}$ denoting days post partum. Female symbol indicates ovary samples and male symbols indicate testes. $\mathrm{C}$ indicates no-template negative controls, and $\mathrm{M}$ indicates marker (100 bp ladder; Promega).

downregulation of the receptors after exposure to exogenous oestrogen ( $\mathrm{d} 25$ of pregnancy cultures: $t E S R 1$ $P<0.479$ and $t E S R 2 P<0.546$ and D0-2 cultures: $t E S R 1$ $P<0.099$ and $t E S R 2 P<0.868$; Fig. 8).

\section{Discussion}

ERs are widely expressed in marsupial reproductive tissues as they are in eutherian mammals (Kuiper et al. 1997). Both marsupial ER genes share a high degree of similarity to the known orthologues from other mammals and vertebrate species. A sexually dimorphic pattern for either tESR1 or tESR2 protein or mRNA expression was not apparent in the undifferentiated ovary or testis. However, as the gonads become sexually dimorphic, receptor expression was localised to different regions of the testis and ovary.

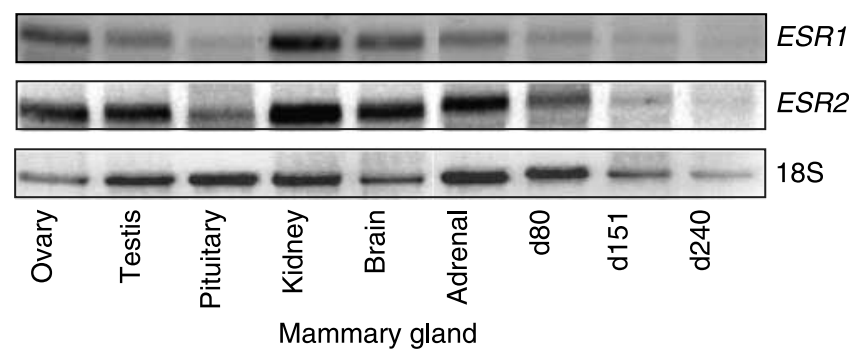

Figure 3 Northern analysis of ESR1 and ESR2 genes. Each lane contains $10 \mu \mathrm{g}$ of total RNA. The northern blot was probed with a labelled ESR1 and ESR2 CDNA fragment of 400 and 300 bp respectively. 18S RNA was used to control for loading (bottom panel). The ESR1 cDNA fragment hybridised to a transcript of $\sim 1.9 \mathrm{~kb}$ (top panel), while the ESR2 fragment hybridised to a transcript of $1.3 \mathrm{~kb}$ (middle panel).

The level of expression varied across tissues for both genes. The kidney had the highest level of expression followed by the brain, ovary, testis and adrenal. Expression for both genes was the lowest in the pituitary and mammary gland.

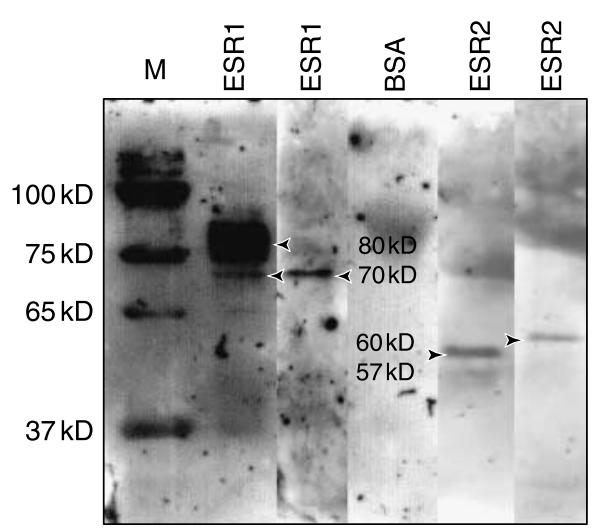

Figure 4 Western blot of rabbit and tammar ovary protein extracts. A rabbit polyclonal antibody raised against ESR1 (Ab-16), and a rabbit polyclonal antibody raised against ESR2 detected a strong signal at $\sim 70$ and $57 \mathrm{kDa}$ respectively in both the rabbit (positive control) and the tammar ovarian protein samples. Nothing was detected in the BSA (negative control) lane in the presence of antibody, indicative of specific binding to the rabbit and wallaby ER proteins. Sizes of the molecular weight markers $(M)$ are indicated on the left. A large band was detected in the rabbit control covering an approximate range of $72-80 \mathrm{kDa}$ and may represent two bands that have overlapped.

\section{Conservation of the marsupial ESR1 and ESR2 orthologues}

The cDNA sequences of both $t E S R 1$ and $t E S R 2$ were highly conserved with orthologues from other vertebrate species encode a predicted protein size of 70 and $57 \mathrm{kDa}$ respectively, similar in size to that of other mammals. No splice variants were detected in this study. This is in contrast to other species such as the mouse and human where multiple splice forms exist for both receptors (Fisher et al. 1997, Bollig \& Miksicek 2000, Stirone et al. 2003). tESR1 was less conserved than $t E S R 1$ when compared to the human orthologues. tESR2 differed in size across all domains, while tESR1 differed only in domains $E$ and $F$ suggesting that ESR2 may be under less selective pressure in mammals.

\section{ERs in the indifferent gonad}

As in rodents, both tESR1 and tESR2 were detected in the cytoplasm of germ and somatic cells of the gonad of both sexes before sexual differentiation, with some rare nuclear staining. The cytoplasmic localisation of the ERs was expected, as there is no oestrogen present in the gonad at this time (Renfree et al. 1992) to activate the receptors and cause their translocation to the nucleus. The occasional nuclear staining observed in some but not all germ cells is unexplained, but could suggest activation of the receptors in ligandindependent or 'non-classical' pathways (Levin 2005, McDevitt et al. 2008). 


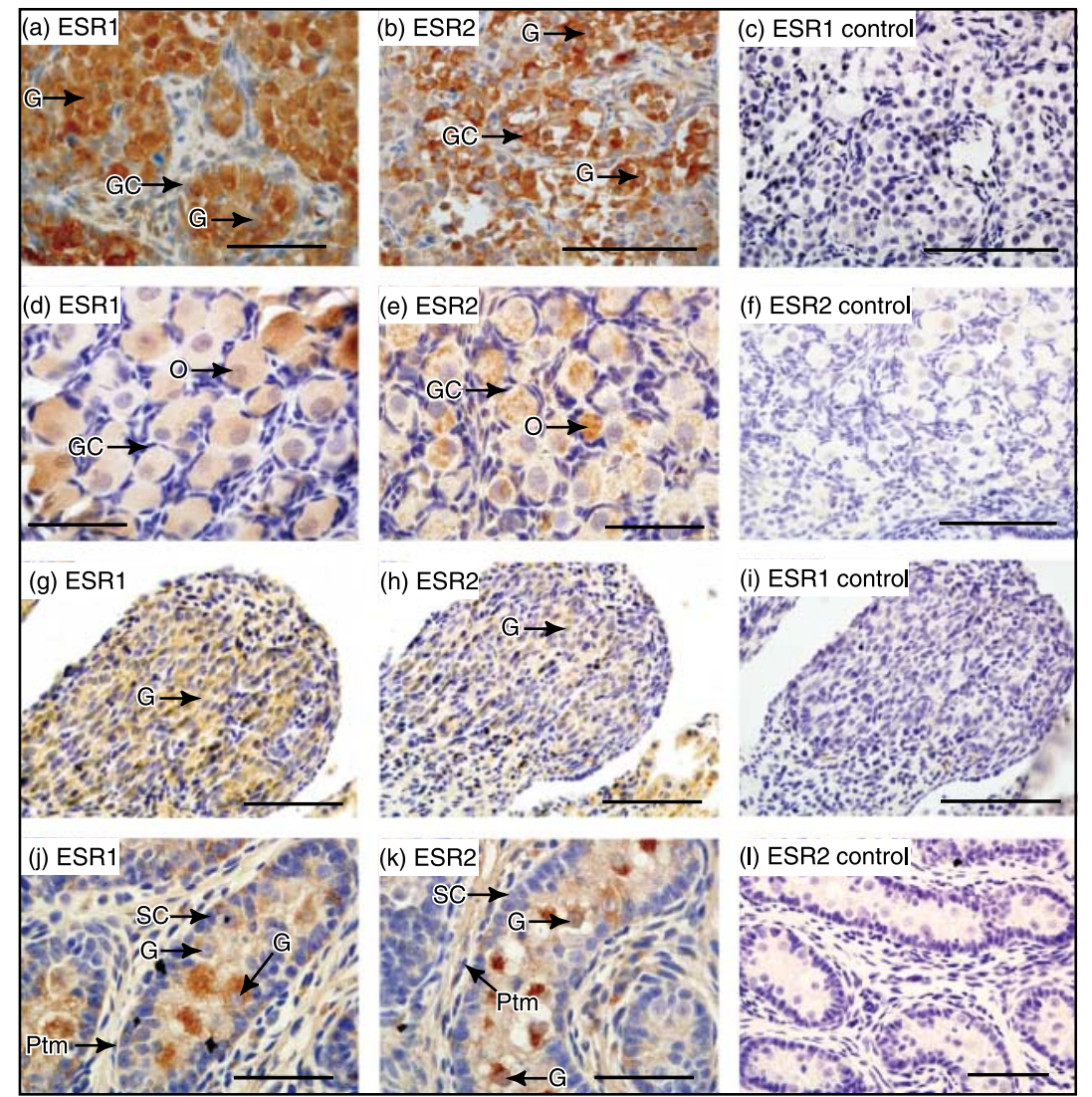

Figure 5 ESR1 and ESR2 in the gonads during development. Both receptors were detectable in the ovary (a-e) and testis (g-k) from early stages of development. In the day 67 pp ovary $(\mathrm{a}-\mathrm{c})$, germ cells $(\mathrm{G})$ have clustered together into germ cell nests. ESR1 (a) and ESR2 (b) were detected in the nucleus and cytoplasm of some, but not all, germ cells. Granulosa cells (GC) surrounding the germ cells were also immunopositive for both ERs, with ESR1 staining strongly in both the nucleus, while ESR2 staining was predominantly cytoplasmic. The interstitial tissue was negative. By day 110 pp, the germ cells have become surrounded by granulosa cells to form primordial follicles. Staining was seen for both ESR1 and ESR2 in the cytoplasm of oocytes $(\mathrm{O})$ and was absent from the granulosa cells (GC). Both ESR1 and ESR2 were expressed in the developing indifferent gonad (g-i; day of birth male). ESR1 was more abundant than ESR2, and staining for both receptors was largely cytoplasmic and appeared to be localised to both the somatic and germ cells. In the day 92 pp testis (j-l), ESR1 (j) protein was weakly cytoplasmic in Sertoli cells (SC) but strong and predominantly cytoplasmic in germ cells. ESR2 (k) protein was weakly cytoplasmic in Sertoli cells and strongly nuclear in most germ cells. No staining was evident for either receptor in the peritubular myoid cells $(\mathrm{Ptm})$. Negative controls $(\mathrm{c}, \mathrm{f}, \mathrm{i}, \mathrm{l})$ represent primary antibody preabsorbed with appropriate blocking peptides (NeoMarkers). Scale bars: (a-c, f, l) $100 \mu \mathrm{m}$; (d-e, j-k) $50 \mu \mathrm{m}$; (g-i) $150 \mu \mathrm{m}$.

\section{ERs in the developing and adult testis}

As in the mouse, both $t E S R 1$ and $t E S R 2$ genes were expressed in the $X X$ and $X Y$ gonads before differentiation, throughout development and in adulthood (Greco et al. 1992, 1993). However, even if ERs are activated by other signals, they are clearly not essential for development since the receptors can be deleted without disrupting sexual development in the mouse (Couse et al. 1995, Korach et al. 1996, Mosselmann et al. 1996, Dixon et al. 1997, Krege et al. 1998, Dupont et al. 2000). In the tammar, the testis cords form by day 2 pp (Renfree \& Short 1988, Renfree et al. 1995, 1996, $2001 b, 2006)$, and both ERs are localised to the Sertoli and germ cells. These observations are similar to those reported for rat ESR2 in which it occurs in multiple cell types, but different from the rat ESR1, which is confined to the Leydig cells (Saunders et al. 1998).
By day $4 \mathrm{pp}$, both receptor proteins were also present in the Leydig cells as in the cat and dog but different to mice and rats (Jefferson et al. 2000, Nie et al. 2002). Peritubular myoid cells in the tammar testis were negative (Fig. 6e and $\mathrm{f}$ ). This pattern remained the same throughout the lengthy period of development in the pouch and in adults. The location and intensity of ER staining varied with age in a similar manner to those of the rat, mouse, human and other primates (O'Donnell et al. 2001).

Sertoli and Leydig cells are important sources of oestrogen in adult mammals, and these two cell types play an important role in aromatisation (Eddy et al. 1996). Tammar Sertoli and Leydig cells synthesise and express both ER receptors, similar to the mouse, suggesting a conserved role for oestrogen in the male reproductive tract (Tsai-Morris et al. 1986, Eddy et al. 1996, O'Donnell et al. 2001). Oestrogen also affects 

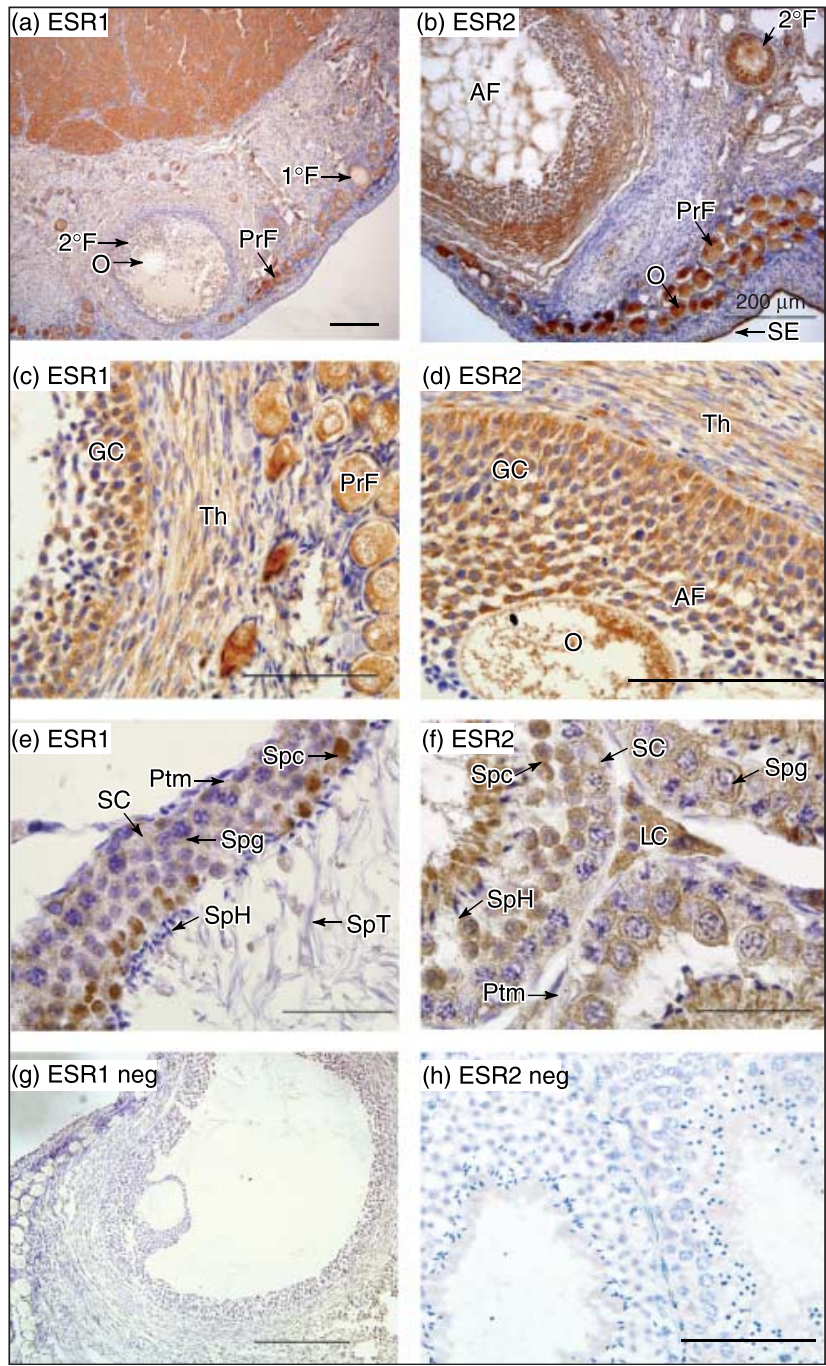

Figure 6 ESR1 and ESR2 in adult ovary $(a-d, g)$ and testis $(e, f, h)$. In the adult female, both ESR1 (a) and ESR2 (b) were nuclear and cytoplasmic in the oocyte $(\mathrm{O})$ at all stages of folliculogenesis, and were particularly strong in the primordial follicles (PrF). Granulosa cells (GC) were predominantly immunopositive in the cytoplasm of all follicles (except primordial follicles) but became nuclear in some cells of primary $\left(1^{\circ} \mathrm{F}\right)$, secondary $\left(2^{\circ} \mathrm{F}\right)$, and antral follicles (AF). The surface epithelium (SE) was stained for ESR2. (c) ESR1 was weakly cytoplasmic in the theca cells (Th) of antral follicles. (d) ESR2 was predominantly cytoplasmic in granulosa and weakly staining in the theca cells of secondary follicles. (e) ESR1 was detected prominently in the nucleus of the spermatocytes (Spc). It was weak and cytoplasmic in the cytoplasm at various stages of sperm development: spermatogonium (Spg). Weak staining occurred in Sertoli cells (SC). There was no obvious staining in the sperm tails (SpT) or heads $(\mathrm{SpH})$. The peritubular myoid cells (Ptm) surrounding the cords were not immunoreactive for ESR1 or ESR2. (f) ESR2 in the adult testis was cytoplasmic in Sertoli cells and primary spermatogonia (Spg), and staining was predominantly cytoplasmic in the spermatocytes (Spc) and was cytoplasmic in the sperm head (SpH). Leydig cells (LC) were strongly stained in both the cytoplasm and nucleus. Negative controls with primary antibody conjugated with blocking peptides are shown for ESR1 (g) and ESR2 (h). Scale bars: (a-d) $200 \mu \mathrm{m}$; (e) $100 \mu \mathrm{m}$; (f) $50 \mu \mathrm{m}$; (g) $200 \mu \mathrm{m}$; (h) $100 \mu \mathrm{m}$.
Sertoli cell division and has an inhibitory effect on Leydig cell proliferation early in development in the rat (Abney \& Myers 1991, Dorrington et al. 1993, Sharpe et al. 1998, Atanassova et al. 1999). tESR1 and tESR2 localisation persisted in Sertoli and Leydig cells in the adult testis, which is consistent with an ongoing role for oestrogen in testicular function (Eddy et al. 1996, Hess et al. 1997, 2001). The co-expression of tESR1 and tESR2 in the developing tammar testis also suggests a conserved role for mediation of oestrogen action through the formation of heterodimeric complexes or a role for ESR2-ESR1 co-regulation in these cells (Lindberg et al. 2003).

Gonadotrophins from the pituitary initiate and maintain spermatogenesis (Ciocca \& Roig 1995). This is mediated by oestrogen feedback in the hypothamicpituitary axis. ESR 1 and ESR2 mRNAs were detected in the tammar hypothalamus and pituitary. Therefore, it is likely that a similar mechanism of oestrogen negative feedback occurs in the hypothalamic-pituitary axis in tammar. tESR1 and tESR2 were also found in germ cells at all stages of development, which is consistent with a role in oestrogen-mediated germ cell maintenance and anti-apoptotic ESR1 receptor-mediated cell survival (Couse \& Korach 1999, Pentikainen et al. 2000). The expression of tESR1 and tESR2 in spermatozoa is similar to that in humans (Durke et al. 1998, Aquila et al. 2004) in whom oestrogen stimulates sperm motility (Lubahn et al. 1993, Korach 1994, Eddy et al. 1996, Hess et al. 1997) and lactate production via ESR1 (O'Donnell et al. 2001). In humans, ESR2 is involved in mediating oestrogen action in mitochondria, calcium influx modulation, ATP production and free-radical species generation (Solakidi et al. 2005).

\section{ERs in the developing and adult ovary}

As development proceeds in the tammar ovary, germ cells aggregate into clusters and divide mitotically within the cortex up to day $25 \mathrm{pp}$, when the germ cells begin to enter meiosis (Alcorn \& Robinson 1983). There was a notable increase in both receptor proteins during this phase, but this was more pronounced for tESR2 than tESR1. Similar observations have been noted in the hamster where both receptors are expressed long before the ovary begins to develop morphologically distinct structures (Yang et al. 2004). From late development (from day $110 \mathrm{pp}$ ) through to adult, both receptors were found strongly expressed in the primary oocytes. This is around the time of the onset of folliculogenesis and initiation of oestrogen production in the tammar (at least by $150-250$ days pp; Tyndale-Biscoe \& Renfree 1987). Since the initial formation of primary oocytes occurs in an environment in oestrogen, the subsequent appearance of oestrogen may negatively regulate $\mathrm{LH}$ and 
Table 3 Distribution of ESR1 and ESR2 in the adult testis and ovary.

\begin{tabular}{|c|c|c|}
\hline Testis & ESR1 & ESR2 \\
\hline Peritubular myoid cells & - & ++ \\
\hline Sertoli cells & $+++/ \mathrm{c}$ & $+++/ c \& n$ \\
\hline Leydig cells & $+++/ c \& n$ & $+++/ c \& n$ \\
\hline Spermatocytes & $+++/ c \& n$ & $+++/ c \& n$ \\
\hline \multicolumn{3}{|l|}{ Spermatids } \\
\hline Round & $+++/ \mathrm{c}$ & $+++/ c$ \\
\hline Elongated & $+++/ \mathrm{c}$ & $+++/ c$ \\
\hline Spermatazoon (tail) & - & +++ \\
\hline Ovary & ESR1 & ESR2 \\
\hline Interstitial tissue & $+++/ c \& n$ & $+++/ c \& n$ \\
\hline \multicolumn{3}{|l|}{ Oocytes } \\
\hline Primordial & $++/ c$ & $++/ \mathrm{c}$ \\
\hline Primary & $++/ c$ & $++/ \mathrm{C}$ \\
\hline Antral & $++/ \mathrm{c}$ & $++/ \mathrm{C}$ \\
\hline \multicolumn{3}{|l|}{ Granulosa cells } \\
\hline Primordial & $++/ c$ & $++/ \mathrm{C}$ \\
\hline Primary & $++/ \mathrm{C}$ & $++/ \mathrm{C}$ \\
\hline Antral & $++/ \mathrm{c}$ & $++/ \mathrm{c}$ \\
\hline \multicolumn{3}{|l|}{ Theca cells } \\
\hline Primary & $++/ c$ & $++/ c$ \\
\hline Antral & $+/ \mathrm{c}$ & $+/ \mathrm{c}$ \\
\hline Stroma & - & - \\
\hline Germinal epithelium & $++/ c \& n$ & $+++/ c \& n$ \\
\hline
\end{tabular}

Staining intensity was scored on a scale of 1-3 with 1 representing light staining and 3 representing dark staining. (c) denotes cytoplasmic staining and $(n)$ denotes nuclear staining. The absence of staining is denoted by $(-)$.

FSH via tESR1 in the hypothalamic-pituitary axis and enhance folliculogenesis via tESR2 in the ovary, as it does in other mammals (Emmen et al. 2005, Glidewell-Kenney et al. 2007). Both receptors are present in tammar Graafian follicles that contain rising levels of oestrogen (Harder et al. 1985) and may be necessary for follicular growth and oocyte maturation. Furthermore, both receptors were co-localised in granulosa and theca cells. To date, this has been reported only in the spiny mouse (Acomys cahirinus) and the common marmoset (Callthrix jacchus; Saunders et al. 2000). Both tESR1 and tESR2 were also detected in the corpus luteum $(\mathrm{CL})$. ER-oestrogen interactions occur in the CL of other species (Telleira et al. 1998, Chiang et al. 2000), and in the tammar, tESR1 in conjunction with ESR2 may similarly be involved in the steroid secretory function of the $\mathrm{CL}$ which is controlled by the $\mathrm{LH}$ surge as well as in mediating autocrine and paracrine intraovarian regulation as observed in the human (Misao et al. 1999) and mice (Byers et al. 1997). Both tESR1 and tESR2 were co-expressed in the granulosa and theca cells of follicles at different stages of development, as seen in the rabbit (Iwai et al. 1991) and human (Tetsuka et al. 1998) but not in mice and rats. In the rat, ESR1 is localised to theca cells and interstitial tissue while ESR2 is present in granulosa cells (Hurst et al. 1995, Couse \& Korach 1999, Sar \& Welsch 1999, Chiang et al. 2000). The overlapping distribution of the ERs in the tammar ovary suggests that they may be similarly regulated.

\section{Effect of exogenous oestrogen on ER expression}

ESR1 protein expression in the gonads exposed to exogenous oestrogen was reduced compared to the control testes because they took on an ovarian appearance. However, receptor mRNA was not significantly lower in treated gonads. Numerous studies show that oestrogen and synthetic oestrogens such as diethylstilboestrol downregulate expression of their own receptors, predominantly affecting ESR1 (Atanassova et al. 2001, Couse et al. 2001, Miyagawa et al. 2004). ER protein half-lives in mammalian cells are regulated in an oestradiol $\left(\mathrm{OE}_{2}\right)$-dependent manner through the ubiquitin-proteasome pathway (Nawaz et al. 1999). Therefore, rapid destruction of the protein may explain the less intense staining of tammar gonads cultured with oestrogen compared to the controls. Since there was only a single (terminal) time point used for analysis (after 5 days of culture) when tissues were sampled, we are unable to determine when the degradation and production of new ER protein occurred or its rate of turnover
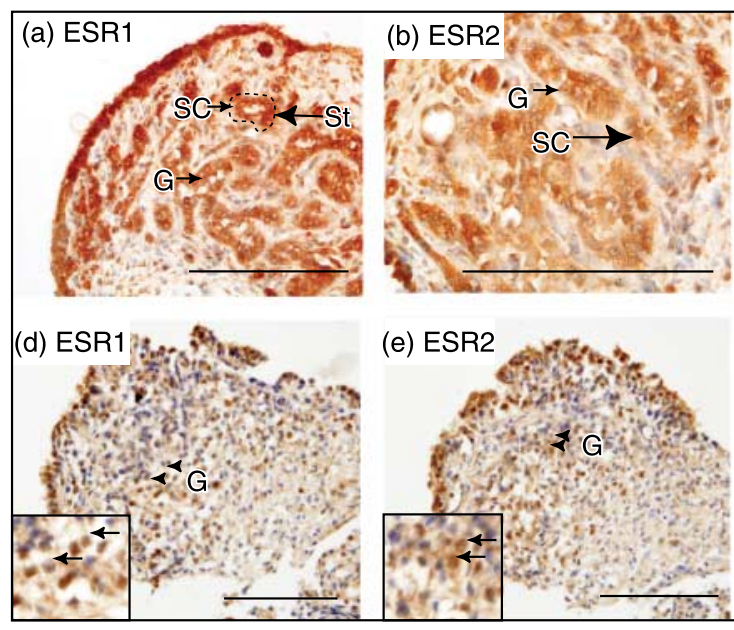
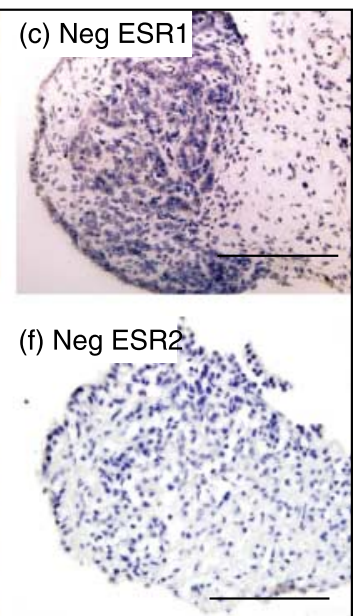

Figure 7 ESR1 and ESR2 in cultured gonads treated with and without oestradiol from day 25 of gestation. Seminiferous tubules (St) formed in the control testes $(\mathrm{a}-\mathrm{c})$. The Sertoli cells (SC) had cytoplasmic staining for ESR1 (a) and ESR2 (b). There was also cytoplasmic staining in the germ cells $(G)$. In the oestrogen-treated gonads $(d-f)$, ESR1 (d) and ESR2 (e) staining was predominantly nuclear in granulosa-like cells and some germ cells (G; arrowheads, enlargements are shown in the bottom left). There were no seminiferous tubules formed in oestradiol cultured gonads. Negative controls (c, f) show no staining when primary antibody is conjugated with blocking peptides for both ESR1 (c) and ESR2 (f). 

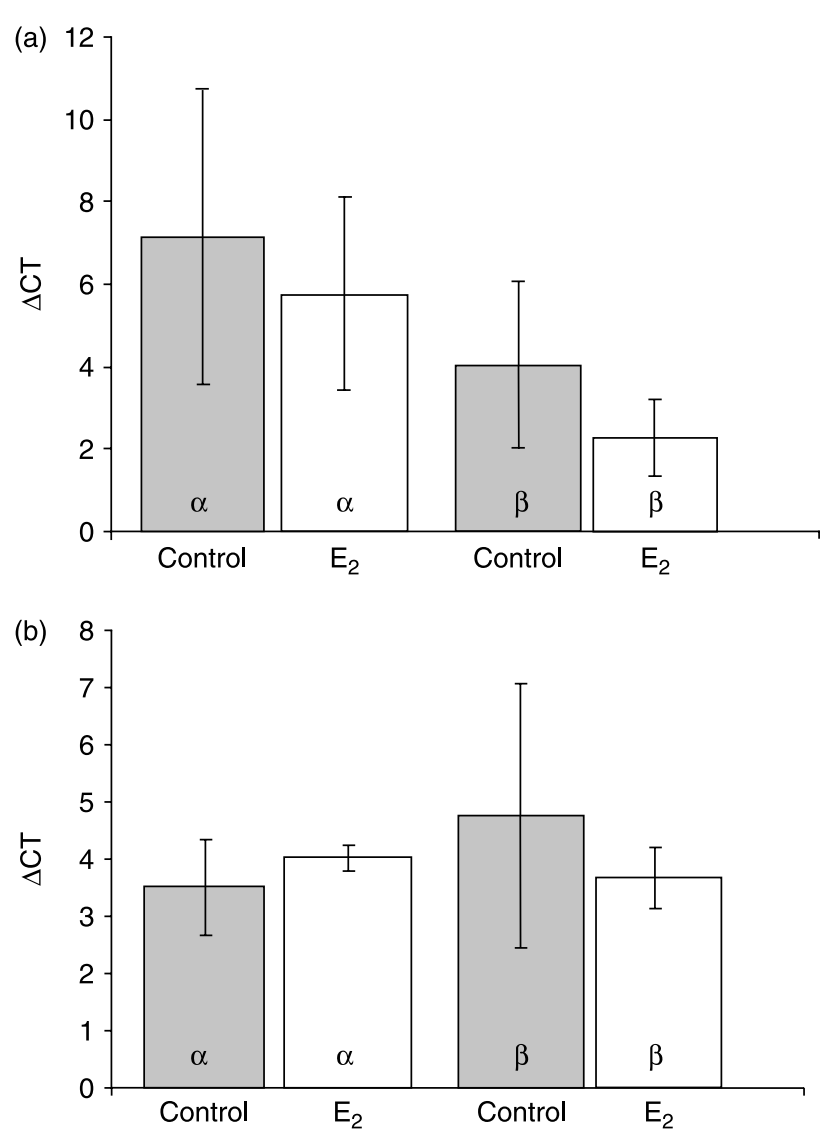

Figure 8 Quantitative PCR of ESR1 $(\alpha)$ and ESR2 $(\beta)$ in XY gonads from (a) day 25 of gestation and (b) day 0-2 pp cultured with and without oestrogen. ESR1 and ESR2 mRNA relative to $\beta$-actin $\left(\Delta C_{t}\right)$ was not significantly affected by the presence or absence of oestrogen, irrespective of the stage of the gonads at which the cultures commence.

during the period of culturing. The pattern of tESR1 localisation in the oestrogen-cultured $X Y$ gonads resembled that of the undifferentiated ovary except for one major characteristic, namely that protein distribution had changed from a primarily cytoplasmic distribution to a primarily nuclear distribution suggesting that the receptors were activated after treatment (Fig. $7 \mathrm{~d}$ and e). Coveney et al. (2001) obtained gonadal sex reversal including germ cell sex reversal, after treatment of neonatal pouch young with $\mathrm{OE}_{2}$. Clearly, culture of $\mathrm{XY}$ gonads with $\mathrm{OE}_{2}$ also induces a degree of gonadal sex reversal.

The expression of $t E S R 2$ in the gonads cultured with oestrogen was similarly not significantly affected. ESR2 may act antagonistically to regulate ESR 1 in the presence of oestrogen without requiring a high or increased level of expression (Pettersson \& Gustafsson 2001, Lindberg et al. 2003). Like tESR1, tESR2 protein was reduced and its distribution changed to become predominantly nuclear localisation following oestrogen exposure. The nuclear translocation of both receptor proteins in the presence of exogenous oestrogen in culture confirms the ability of the receptors to respond functionally to the ligand even at early developmental stages.

Coveney et al. (2001) obtained gonadal and germ cell sex reversal after oestrogen treatments of neonatal pouch young for 25 days. In our study, culture of XY gonads with oestrogen also induced morphological sex reversal. We have shown that the receptors can respond to exogenous oestrogen at this early stage and translocate to the nucleus in its presence, but we cannot exclude the potential for non-classical signaling pathways in this process. However, evidence from the ARKO and doubleER $(\alpha / \beta E R K O)$ knockout mice suggest that the effects of the classical and non-classical pathway are not required for any aspect of early sexual differentiation. Nevertheless, gonadal sex reversal in the presence of oestrogen provides a powerful tool for understanding the interplay of genes and hormones in early gonadal differentiation. We hypothesise that ERs in the indifferent mammalian gonad are capable of transducing the signals from exogenous oestrogen to downregulate the testis differentiation pathway and allow ovarian differentiation to occur. However, the selective forces that maintained conserved ER expression in this tissue remain unknown.

\section{Materials and Methods}

\section{Animals}

Tammar wallabies from Kangaroo Island (South Australia) were held in open grassy yards in our breeding colony. Natural diet was supplemented with lucerne cubes, oats and fresh vegetables and water ad libitum. All experiments were approved by the University of Melbourne Animal Experimentation Ethics Committees, and animal handling and husbandry were in accordance with the National Health and Medical Research Council of Australia (2004) guidelines.

Timed births were obtained after initiating pregnancy by removal of pouch young (RPY), which reactivates the quiescent, diapausing blastocyst during the breeding season (Tyndale-Biscoe \& Renfree 1987). The day of RPY is designated day 0 of the 26.5-day pregnancy (Tyndale-Biscoe \& Renfree 1987). For foetal tissue collection, adult females were killed by anaesthetic overdose $(60 \mathrm{mg} / \mathrm{ml}$ sodium pentobarbitone to effect) from day 23 to day 25 of gestation, and the reproductive tract was removed. Foetuses were removed from the tract, and both gonads and mesonephroi were dissected out. From each animal, one gonad was snap frozen for RNA analysis, and the other was fixed in 4\% paraformaldehyde (PFA) for histological analysis. A piece of tail was collected from each foetus for sexing by PCR for the presence of SRY (Harry et al. 1995). Pouch young were removed from mothers (RPY) at d1-13 $(n=5), 23-24(n=2), 49(n=2), 60 \quad(n=2), 72 \quad(n=2), 90$ $(n=2), 150(n=2$ ovaries) and ( $n=2$ testes), and d300 $(n=2)$ ovaries. Day 0-20 pouch young were killed by decapitation, and older pouch young were anaesthetised with an i.p. injection of sodium pentobarbitone then decapitated. Adult ovaries $(n=10)$ and testes $(n=10)$ were collected for 
histology and gene expression analysis as previously described (Renfree \& Tyndale-Biscoe 1978). Non-reproductive tissues were collected from adult females, including liver $(n=5)$, adrenal $(n=5)$, pituitary $(n=5)$, kidney $(n=5)$ and hypothalamus $(n=5)$.

\section{Culture of $X Y$ gonads with oestrogen}

Pairs of gonads with mesonephroi intact were collected from male foetuses $(n=10)$ at $\mathrm{d} 25$ of gestation. Gonads were cultured according to the method described by Martineau et al. (1997). From each pair, one gonad was cultured without oestrogen (control), and the other was cultured with oestrogen. The control medium consisted of DMEM (Thermotrace, Victoria, Australia) supplemented with FCS (+10\%) (Thermotrace), penicillin-streptomycin (penicillin-G, 100 IU; streptomycin $100 \mu \mathrm{g} / \mathrm{ml}$, Thermotrace), insulin-transferrin-selenium (100 $\mu \mathrm{g} / \mathrm{ml}$, Gibco) and L-glutamine (2 mmol/ml, Gibco). The oestrogen medium was the control medium supplemented with oestrogen $(0.1 \mathrm{ng} / \mu \mathrm{l})$. Gonads were cultured in organ dishes (Falcon, York, UK) on fine wire that supported the gonad at the surface of the culture medium. Gonads were cultured for 5 days in a humidified environment at $37^{\circ} \mathrm{C}$ in $6 \% \mathrm{CO}_{2}$ in air, and culture media were replenished every second day. After culture, one of each pair of cultured gonads was fixed in $4 \%$ PFA for histology, and one was snap frozen for RNA analysis.

\section{RNA extraction and RT-PCR}

RNA was extracted from small tissues ( $<80 \mathrm{mg}$ ) using the GenElute Mammalian Total RNA Miniprep Kit (Sigma, \#RTN70) as per the manufacturer's instructions. Tissues weighing more than $100 \mathrm{mg}$ were homogenised in $1 \mathrm{ml}$ RNAwiz (\#9736; Ambion, Victoria, Australia). Up to $5 \mu \mathrm{g}$ of RNA was treated using the Superscript III First Strand Synthesis System for RT-PCR (Invitrogen, \#18080-051) to generate first strand cDNA according to the manufacturer's instructions.

\section{PCR}

PCR conditions were as follows: initial incubation of $94{ }^{\circ} \mathrm{C}$ for $2 \mathrm{~min}$, followed by 36 cycles of $94^{\circ} \mathrm{C}$ for $1 \mathrm{~min}$, primer-specific annealing temperature for $1 \mathrm{~min}$, and $72{ }^{\circ} \mathrm{C}$ for $1 \mathrm{~min}$, with a final extension at $72{ }^{\circ} \mathrm{C}$ for $5 \mathrm{~min}$. Promega Taq DNA polymerase $\mathrm{B}$ (Promega, \#M1661) and accompanying reagents were used, with $1.5 \mu \mathrm{M} \mathrm{MgCl}_{2}$ and $0.2 \mu \mathrm{M}$ each (dNTPs).

\section{Quantitative PCR}

Quantitative real-time PCR (qPCR) using a SYBR green Mastermix (Quantitect; Qiagen) and an Opticon 2 Monitor (Geneworks; MJ Research, Waltham, MA, USA) was used to measure relative ESR1 and ESR2 gene expression in XY oestrogen-cultured and control gonads. Specific primers were designed to optimise qPCR sensitivity (Table 2). All qPCR reactions were performed in triplicate using 96-well multiplates and a reaction volume of $20 \mu \mathrm{l}$, and both ESR1 and ESR2 were measured relative to $\beta$-actin. The data were analysed using the $\Delta C_{\mathrm{t}}$ method described by Pfaffl (2001). $P$ values were calculated using a standard student's $t$-test. The conditions used for qPCR were as follows: $50^{\circ} \mathrm{C}$ for $10 \mathrm{~min}, 95^{\circ} \mathrm{C}$ for $15 \mathrm{~min}$, followed by 39 cycles of $95^{\circ} \mathrm{C}$ for $30 \mathrm{~s}, 59^{\circ} \mathrm{C}$ for $20 \mathrm{~s}, 72{ }^{\circ} \mathrm{C}$ for $40 \mathrm{~s}, 78^{\circ} \mathrm{C}$ for $1 \mathrm{~s}, 72{ }^{\circ} \mathrm{C}$ (all genes were optimised to this temperature) for $1 \mathrm{~min}$, and $15^{\circ} \mathrm{C}$ until the end of the reaction.

\section{Northern blot}

Total RNA was extracted from ovary, testis, kidney, liver, adrenal, pituitary, hypothalamus and mammary gland, for northern analysis of $t E S R 1$ and $t E S R 2$ mRNA expression, according to standard methods (Zeta-Probe GT Genomic Tested Blotting Membrane (Bio-Rad, \#162-0196; Megaprime Labelling System, Amersham \#RPN1604/5). An ESR1-specific cDNA probe of $400 \mathrm{bp}$ and ESR2-specific cDNA probe of $\sim 300 \mathrm{bp}$ were used to detect the receptors in the tissues mentioned above. Membranes were exposed to Fuji medical X-ray film (Super RX, \#497690; Hanimex, Brookvale, NSW, Australia), and films were developed using an All-pro 100 Plus XOMat machine (\#2792; Nuvosolutions/All imagingCorps, Victoria, Australia; see western blot section).

\section{Immunohistochemistry}

Tissues were fixed in $4 \%$ PFA and stored for $2-3 \mathrm{~h}$ at $4{ }^{\circ} \mathrm{C}$. The tissue was then rinsed in PBS three times for 30 min each and finally stored in $70 \%$ ethanol $(\mathrm{EtOH})$ at $4{ }^{\circ} \mathrm{C}$. Tissues were sectioned at $6 \mu \mathrm{m}$. Polyclonal rabbit antibodies Ab-16 (ESR1, Neomarkers \#RB-1493-P1) and Ab-24 (ESR2, Neomarkers \#RB-037-P) were diluted to a final concentration of $1: 100$, and a biotinylated secondary goat anti-rabbit antibody was used with ABComplex/HRP kit (DAKO, \#K0355) and colour was developed with DAB Chromagen tablets (DAKO, \#S3000). Sections were counterstained with haematoxylin. Appropriate negative control reactions were run in parallel (ESR1 peptide 1:20, Neomarkers, \#PP-1493 and ESR2, Neomarkers, \#PP-037-P). Follicles in ovarian sections were classified as previously described (Tyndale-Biscoe \& Renfree 1987, Richings et al. 2006).

\section{Western blot analyses}

Ovarian tissue was homogenised in a radio-immunoprotein assay buffer (50 mM Tris base, $150 \mathrm{mM} \mathrm{NaCl}, 1 \% \mathrm{NP}-40$, $0.25 \%$ Na-deoxycholate) supplemented with protease inhibitors (Protease Inhibitor Cocktail Set V, \#535141; $1 \mu \mathrm{l} / \mathrm{ml}$; Calbiochem, Merck). The protein extract was sonicated, on ice, seven times for periods of $15 \mathrm{~s}$ on and $15 \mathrm{~s}$ off. Twenty-five micrograms of extracted protein was analysed by SDS-PAGE using the discontinuous buffer system described by Laemmli (1970). Proteins were transferred onto nitrocellulose membrane using a semi-dry trans cell electro-blotter (Tr4ansblot SD cell \#22981, Bio-Rad) at $15 \mathrm{~V}$ for $15 \mathrm{~min}$. Stored membranes were blocked overnight with $45 \%$ fish gelatin in $1 \times$ PBS-Tween at $4{ }^{\circ} \mathrm{C}$. Primary antibody was added at a concentration of 1:500 and incubated at room temperature for $1 \mathrm{~h}$. The second antibody was incubated at room temperature at a concentration of 1:1000 for $1 \mathrm{~h}$. 
The membrane was exposed to Hybond ECL hyperfilm using Luminol reagents (\#sc-2048; Santa Cruz Biotechnology, Santa Cruz, CA, USA) 3 min and developed using an All-pro 100 Plus XOMat machine (Nuvosolutions/All imagingCorps \#2792).

\section{Declaration of interest}

The authors declare that there is no conflict of interest that could be perceived as prejudicing the impartiality of the research reported.

\section{Funding}

This study was supported by grants from the National Health and Medical Research Council (NHMRC); M B Renfree was supported by an Australian Research Council Federation Fellowship; A J Pask was supported by an NHMRC RD Wright Fellowship, N M Richings supported by Australian Research Council grant to M B Renfree, G Shaw and Prof. Temple-Smith. N E Calatayud was supported by a Scholarship from the University of Melbourne and Mr and Mrs Calatayud.

\section{Acknowledgements}

We especially thank Scott Brownlees and Kerry Martin for their continued and dedicated assistance with the animals; Bruce Abaloz for assistance with histology; Dr Danielle Hickford for advice with histology, immunohistochemistry and culture, and Helen Gehring, Dr Kylie Cane, Elizabeth Pharo, and Coralie Reich for advice and assistance with molecular biology and bioinformatics. Animals were held under permits from the Victorian Department of Sustainability and Environment.

\section{References}

Abney TO \& Myers RB 1991 17 $\beta$-Estradiol inhibition of Leydig cell regeneration in the ethane dimethylsulfonate-treated mature rat. Journal of Andrology 12 295-304.

Alcorn GT \& Robinson ES 1983 Germ cell development in female pouch young of the tammar wallaby (Macropus eugenii). Journal of Reproduction and Fertility 67 319-325.

Aquila S, Sisci D, Gentile M, Middea E, Catalano S, Carpino A, Rago V \& Ando S 2004 Estrogen receptor (ER) $\alpha$ and ER $\beta$ are both expressed in human ejaculated spermatozoa: evidence of their direct interaction with phosphatidylinositol-3-OH kinase/Akt pathway. Journal of Clinical Endocrinology and Metabolism 89 1443-1451.

Atanassova N, McKinnell C, Walker M, Turner KJ, Fisher JS, Morley M, Millar MR, Groome NP \& Sharpe RM 1999 Permanent effect of neonatal estrogen exposure in rats on reproductive hormone levels. Sertoli cell number, and the efficiency of spermatogenesis in adulthood. Endocrinology 140 5346-5373.

Atanassova N, McKinnell C, Williams K, Turner KJ, Fisher JS, Saunders PT, Millar MR \& Sharpe RM 2001 Age-, cell- and region-specific immunoexpression of estrogen receptor $\alpha$ (but not estrogen receptor $\beta$ ) during postnatal development of the epididymis and vas deferens of the rat and disruption of this pattern by neonatal treatment with diethylstilbestrol. Endocrinology 142 874-886.

Bininda-Emonds OR, Cardillo M, Jones KE, MacPhee RD, Beck RM, Grenyer R, Price SA, Vos RA, Gittleman JL \& Purvis A 2007 The delayed rise of present day mammals. Nature 446 507-512.

Bjornstrom L \& Sjobergp M 2005 Mechanisms of estrogen receptor signalling: convergence of genomic and nongenomic actions on target genes. Molecular Endocrinology 19 833-842.
Bollig A \& Miksicek RJ 2000 An estrogen receptor-alpha splicing variant mediates both positive and negative effects on gene transcription. Molecular Endocrinology 14 634-649.

Britt KL \& Findlay JK 2003 Regulation of the phenotype of ovarian somatic cells by estrogen. Molecular and Cellular Endocrinology 202 11-17.

Britt KL, Stanton PG, Misso M, Simpson ER \& Findlay JK 2004 The effects of estrogen on the expression of genes underlying the differentiation of somatic cells in the murine gonad. Endocrinology 145 3950-3960.

Burns RK 1956 Transformation of embryonic testes of opossum in ovotestes or in ovary under the effect of female hormone estradiol dipropionate. Archives of Anatomy and Pathology 45 173-202.

Burns RK 1961 The role of hormones in the differentiation of sex. In Sex and Internal Secretions, pp 76-158. Ed. WC Young. London: Tindall and Co.

Byers M, Kuiper GG, Gustafsson JA \& Park-Sarge OK 1997 Estrogen receptor-beta mRNA expression in rat ovary: down-regulation by gonadotropins. Molecular Endocrinology 11 172-182.

Chenna R, Sugawara H, Koike T, Lopez R, Gibson TJ, Higgins DG \& Thompson JD 2003 Multiple sequence alignment with the Clustal series of programs. Nucleic Acids Research 31 3497-3500.

Chiang CH, Cheng KW, Igarashi S, Nathwani PS \& Leung PC 2000 Hormonal regulation of estrogen receptor alpha and beta gene expression in human granulosa-luteal cells in vitro. Journal of Clinical Endocrinology and Metabolism 85 3828-3839.

Ciocca DR \& Roig LM 1995 Estrogen receptors in human nontarget tissues: biological and clinical implication. Endocrine Reviews 16 35-62.

Couse JF \& Korach KS 1999 Estrogen receptor null mice: what have we learned and where will they lead us? Endocrine Reviews 20 358-417.

Couse JF, Curtis SW, Washburn TF, Eddy EM, Schomberg DW \& Korach KS 1995 Disruption of the mouse oestrogen receptor gene: resulting phenotypes and experimental findings. Biochemical Society Transactions 23 929-935.

Couse JF, Curtis Hewitt S \& Korach KS 2000 Receptor null mice reveal contrasting roles for estrogen receptor alpha and beta in reproductive tissues. Journal of Steroid Biochemistry and Molecular Biology $\mathbf{7 4}$ 287-296.

Couse JE, Mahato D, Eddy EM \& Korach KS 2001 Molecular mechanism of estrogen action in the male: insights from the estrogen receptor null mice. Reproduction, Fertility, and Development 13 211-219.

Coveney D, Shaw G \& Renfree MB 2001 Estrogen-induced gonadal sex reversal in the tammar wallaby. Biology of Reproduction 65 613-621.

Dixon D, Couse JF \& Korach KS 1997 Disruption of the estrogen receptor gene in mice. Toxicologic Pathology 25 518-520.

Dorrington JH, Bendell JJ \& Khan SA 1993 Interactions between FSH, estradiol-17 beta and tranforming growth factor-beta regulate growth and differentiation in the rat gonad. Journal of Steroid Biochemistry and Molecular Biology 44 441-447.

Dupont S, Krust A, Gansmuller A, Dierich A, Chambon P \& Mark M 2000 Effect of single and compound knockouts of estrogen receptors alpha (ERalpha) and beta (ERbeta) on mouse reproductive phenotypes. Development 127 4277-4291.

Dupont S, Dennefeld C, Krust A, Chambon P \& Mark M 2003 Expression of Sox9 in granulosa cells lacking the estrogen receptors, ERalpha and ERbeta. Developmental Dynamics 226 103-106.

Durke TJ, Mueller M \& Zinaman M 1998 Identification of estrogen receptor protein and messenger ribonucleic acid in human spermatozoa. American Journal of Obstetrics and Gynecology 178 1288-1297.

Eddy EM, Washburn TF, Bunch DO, Goulding EH, Gladen BC, Lubahn DB \& Korach KS 1996 Targeted disruption of the estrogen receptor gene in male mice causes alteration of spermatogenesis and infertility. Endocrinology 137 4796-4805.

Emmen JM, Couse JF, Elmore SA, Yates MM, Kissling GE \& Korach KS 2005 In vitro growth and ovulation of follicles from ovaries of estrogen receptor $(E R) \alpha$ and $E R \beta$ null mice indicate a role for $E R \beta$ in follicular maturation. Endocrinology 146 2817-2826.

Fisher JS, Millar MR, Majdic G, Saunders PT, Fraser HM \& Sharpe RM 1997 Immunolocalisation of oestrogen receptor-alpha within the testis and excurrent ducts of the rat and marmoset monkey from perinatal life to adulthood. Journal of Endocrinology 153 485-495.

Fisher CR, Graves KH, Parlow AF \& Simpson ER 1998 Characterisation of mice deficient in aromatase (ArKO) because of targeted disruption of the cyp 19 gene. PNAS 95 6965-6970. 
Gist DH, Bradshaw S, Morrow CM, Congdon JD \& Hess RA 2007 Estrogen response system in the reproductive tract of the male turtle: an immunocytochemical study. General and Comparative Endocrinology $15127-33$.

Glidewell-Kenney C, Hurley LA, Pfaff L, Weiss J, Levine JE \& Jameson JL 2007 Nonclassical estrogen receptor $\alpha$ signaling mediates negative feedback in the female mouse reproductive axis. PNAS 104 8173-8177.

Greco TL, Furlow JD, Duello TM \& Gorski J 1992 Immunodetection of estrogen receptors in fetal and neonatal male mouse reproductive tracts. Endocrinology 130 421-429.

Greco TL, Duello TM \& Gorski J 1993 Estrogen receptors, estradiol, and diethylstilbestrol in early development: the mouse as a model for the study of estrogen receptors and estrogen sensitivity in embryonic development of male and female reproductive tracts. Endocrine Reviews 14 59-71.

Harder JD, Hinds LA, Horn CA \& Tyndale-Biscoe CH 1985 Effects of removal in late pregnancy of the corpus luteum, Graafian follicle or ovaries on plasma progesterone, oestradiol, $\mathrm{LH}$, parturition and post-partum oestrus in the tammar wallaby, Macropus eugenii. Journal of Reproduction and Fertility 75 449-459.

Harry JL, Koopman P, Brennan FE, Graves JA \& Renfree MB 1995 Widespread distribution of the testis-determining gene SRY in a marsupial. Nature Genetics 11 347-349.

Hess RA, Bunick D, Lee KH, Bahr J, Taylor JA, Korach KS \& Lubahn DB 1997 A role for estrogens in the male reproductive system. Nature 390 509-512.

Hess RA, Bunick D \& Bahr J 2001 Oestrogen, its receptors and function in the male reproductive tract - a review. Molecular and Cellular Endocrinology 178 29-38.

Hou Q \& Gorski J 1993 Estrogen receptor and progesterone receptor genes are expressed differentially in mouse embryos during preimplantation development. PNAS 90 9460-9464.

Hou Q, Paria BC, Mui C, Dey SK \& Gorski J 1996 Immunolocalization of estrogen receptor protein in the mouse blastocyst during normal and delayed implantation. PNAS 93 2376-2381.

Hurst BS, Zilberstein M, Chou JY, Litman B, Stephens J \& Leslie KK 1995 Estrogen receptors are present in human granulosa cells. Journal of Clinical Endocrinology and Metabolism 80 229-232.

Iwai T, Fujii S, Nanbu Y, Nonogaki H, Konishi I, Mori T \& Okamura H 1991 Effect of human chorionic gonadotropin on the expression of progesterone receptors and estrogen receptors in rabbit ovarian granulosa cells and the uterus. Endocrinology 129 1840-1848.

Jefferson WN, Couse JF, Banks EP, Korach KS \& Newbold RR 2000 Expression of estrogen receptor beta is developmentally regulated in reproductive tissues of male and female mice. Biology of Reproduction 62 310-317.

Katsu Y, Kohno S, Oka T, Mitsui N, Tooi O, Santo N, Urushitani H, Fukumoto Y, Kuwabara K, Ashikaga K et al. 2006 Molecular cloning of estrogen receptor alpha (ERalpha; ESR1) of the Japanese giant salamander, Andrias japonicus. Molecular and Cellular Endocrinology 257-258 84-94.

Korach KS 1994 Insights from the study of animals lacking functional estrogen receptor. Science 266 1524-1527.

Korach KS, Couse JF, Curtis SW, Washburn TF, Lindzey J, Kimbro KS, Eddy EM, Migliaccio S, Snedeker SM, Lubahn DB et al. 1996 Estrogen receptor gene disruption: molecular characterization and experimental and clinical phenotypes. Recent Progress in Hormone Research 51 159-186.

Krege JH, Hodgin JB, Couse JF, Enmark E, Warner M, Mahler JF, Sar M, Korach KS, Gustafsson JA \& Smithies O 1998 Generation and reproductive phenotypes of mice lacking estrogen receptor beta. PNAS 95 15677-15682.

Kuiper GG, Carlsson B, Grandien K, Enmark E, Haggblad J, Nilsson S \& Gustafsson JA 1997 Comparison of the ligand binding specificity and transcript tissue distribution of estrogen receptors alpha and beta. Endocrinology 138 863-870.

Kumar V, Green S, Stack G, Berry M, Jin JR \& Chambon P 1987 Functional domains of the human estrogen receptor. Cell 51 941-951.

Laemmli UK 1970 Cleavage of structural proteins during the assembly of the head of bacteriophage T4. Nature 227 680-685.

Levin ER 2005 Integration of the extranuclear and nuclear actions of estrogen. Molecular Endocrinology 19 1951-1959.
Lindberg MK, Moverare S, Skrtic S, Gao H, Dahlman-Wright K, Gustafsson JA \& Ohlsson C 2003 Estrogen receptor (ER)- $\beta$ reduces ER $\alpha$-regulated gene transcription, supporting a "ying yang" relationship between ER $\alpha$ and ER $\beta$ in mice. Molecular Endocrinology 17 203-208.

Lubahn DB, Moyer JS, Golding TS, Couse JF, Korach KS \& Smithies O 1993 Alteration of reproductive function but not prenatal sexual development after insertional disruption of the mouse estrogen receptor gene. PNAS $9011162-11166$.

Mak P, Ho SM \& Callard IP 1983 Characterization of an estrogen receptor in the turtle testis. General and Comparative Endocrinology 52 182-189.

Martineau J, Nordqvist K, Tilmann C, Lovell-Badge R \& Capel B 1997 Male-specific cell migration into the developing gonad. Current Biology 7 958-968.

McDevitt MA, Glidewell-Kenney C, Jimenez MA, Ahearn PC, Weiss J, Jameson JL \& Levine JE 2008 New insights into the classical and non-classical actions of estrogen: evidence from estrogen receptor knock-out and knock-in mice. Molecular and Cellular Endocrinology $29024-30$.

Misao R, Nakanishi Y, Sun WS, Fujimoto J, Iwagaki S, Hirose R \& Tamaya T 1999 Expression of oestrogen receptor alpha and beta mRNA in corpus luteum of human subjects. Molecular Human Reproduction 5 17-21.

Mittwoch U 1993 Male sexual development in "a sea of oestrogen". Lancet 342 123-124.

Miyagawa S, Katsu Y, Watanabe H \& Iguchi T 2004 Estrogen-independent activation of erbBs signaling and estrogen alpha in the mouse vagina exposed neonatally to diethylbestrol. Oncogene 23 340-349.

Miyashita K, Shimizu N, Osanai S \& Miyata S 2000 Sequence analysis of the P450 aromatase and estrogen receptor genes in the Xenopus ovary. Journal of Steroid Biochemistry and Molecular Biology 75 101-107.

Mosselmann S, Polman J \& Dijkema R 1996 ER beta identification and characterization of a novel human estrogen receptor. FEBS Letters 392 $49-53$.

National Health and Medical Research Council 2004 Australian Code of Practice for the Care and Use of Animals for Scientific Purposes, edn 7. Canberra ACT: Australian Government.

Nawaz Z, Lonard DM, Dennis AP, Smith CL \& O'Malley BW 1999 Proteasome-dependent degradation of the human estrogen receptor. PNAS 96 1858-1862.

Nie R, Zhou Q, Jassim E, Saunders PT \& Hess RA 2002 Differential expression of estrogen receptors $\alpha$ and $\beta$ in the reproductive tracts of adult male dogs and cats. Biology of Reproduction 66 1161-1168.

O'Donnell L, Robertson KM, Jones ME \& Simpson ER 2001 Estrogen and spermatogenesis. Endocrine Reviews 22 289-318.

Pace P, Taylor J, Suntharalingam S, Coombes RC \& Ali S 1997 Human estrogen receptor beta binds DNA in a manner similar to and dimerizes with estrogen receptor alpha. Journal of Biological Chemistry 272 25832-25838.

Pavao M \& Traish AM 2001 Estrogen receptor antibodies: specificity and utility in detection, localization and analyses of estrogen receptor alpha and beta. Steroids 66 1-16.

Pentikainen V, Erkkila K, Suomalainen L, Parvinen M \& Dunkel L 2000 Estradiol acts as a germ cell survival factor in the human testis in vitro. Journal of Clinical Endocrinology and Metabolism 85 2057-2067.

Pettersson K \& Gustafsson JA 2001 Role of estrogen receptor beta in estrogen action. Annual Reviews of Physiology 63 165-169.

Pettersson K, Grandien K, Kuiper GG \& Gustafsson JA 1997 Mouse estrogen receptor beta forms estrogen response element-binding heterodimers with estrogen receptor alpha. Molecular Endocrinology 11 1486-1496.

Pfaffl MW 2001 A new mathematical model for relative quantification in real-time RT-PCR. Nucleic Acids Research 29 e45.

Pieau C \& Dorizzi M 2004 Oestrogens and temperature-dependent sex determination in reptiles: all is in the gonads. Journal of Endocrinology 181 367-377.

Pieau C, Dorizzi M, Richard-Mercier N \& Desvages G 1998 Sexual differentiation of gonads as a function of temperature in the turtle Emys orbiculari: endocrine function, intersexuality and growth. Journal of Experimental Zoology 281 400-408.

Renfree MB \& Blanden DR 2000 Progesterone and oestrogen receptors in the female genital tract throughout pregnancy of the tammar wallaby. Journal of Reproduction and Fertility 119 121-128. 
Renfree MB \& Short RV 1988 Sex determination in marsupials: evidence for a marsupial-eutherian dichotomy. Philosophical Transactions of the Royal Society of London. Series B 322 41-54.

Renfree MB \& Tyndale-Biscoe CH 1978 Manipulation of marsupial embryos and pouch young. In Methods of Mammalian Reproduction, pp 307-31. Ed. JC Daniel. New York: Academic Press.

Renfree MB, Wilson JD, Short RV, Shaw G \& George FW 1992 Steroid hormone content of the gonads of the tammar wallaby during sexual differentiation. Biology of Reproduction 47 644-647.

Renfree MB, Harry JL \& Shaw G 1995 The marsupial male: a role model for sexual development. Philosophical Transactions of the Royal Society of London. Series B 350 243-251.

Renfree MB, O W-S, Short RV \& Shaw G 1996 Sexual differentiation of the urogenital system of the fetal and neonatal tammar wallaby, Macropus eugenii. Anatomy and Embryology 194 111-134.

Renfree MB, Coveney D \& Shaw G 2001 a The influence of oestrogen on the developing male marsupial. Reproduction, Fertility, and Development 13 231-240.

Renfree MB, Pask AJ \& Shaw G $2001 b$ Sex down under: the differentiation of sexual dimorphisms during marsupial development. Reproduction, Fertility, and Development 13 679-690.

Renfree MB, Pask AJ \& Shaw G 2006 Sexual development in the marsupial male. Australian Journal of Zoology 54 151-158.

Richings NM, Shaw G, Temple-Smith PD \& Renfree MB 2006 Growth and histology of ovarian follicles after cold storage in the tammar wallaby. Reproduction, Fertility, and Development 18 677-688.

Rosenfeld CS, Ganjam VK, Taylor JA, Yuan X, Stiehr JR, Hardy MP \& Lubahn DB 1998 Transcription and translation of estrogen receptor- $\beta$ in the male reproductive tract of estrogen receptor- $\alpha$ knock-out and wild-type mice. Endocrinology 139 2982-2987.

Sar M \& Welsch F 1999 Differential expression of estrogen receptor- $\beta$ and estrogen receptor- $\alpha$ in the rat ovary. Endocrinology 140 963-971.

Saunders PT, Fisher JS, Sharpe RM \& Millar MR 1998 Expression of oestrogen receptor $\beta$ (ER $\beta)$ occurs in multiple cell types, including some germ cells, in the rat testis. Journal of Endocrinology 156 R13-R17.

Saunders PT, Millar MR, Williams K, Macpherson S, Harkiss D, Anderson RA, Orr B, Groome NP, Scobie G \& Fraser HM 2000 Differential expression of estrogen receptor- $\alpha$ and $-\beta$ and androgen receptor in the ovaries of marmosets and humans. Biology of Reproduction 63 1098-1105.
Sharpe RM, Atanassova N, McKinnell C, Parte P, Turner KJ, Fisher JS Kerr JB, Groome NP, Macpherson S, Millar MR et al. 1998 Abnormalities in functional development of the Sertoli cells in rats treated neonatally with diethylstilbestrol: a possible role for estrogens in Sertoli cell development. Biology of Reproduction 59 1084-1094.

Shaw G, Renfree MB, Short RV \& O W-S 1988 Experimental manipulation of sexual differentiation in wallaby pouch young treated with exogenous steroids. Development 104 689-701.

Solakidi S, Psarra AM, Nikolaropoulos S \& Sekeris CE 2005 Estrogen receptors aplpha and beta and androgen receptor in human sperm: localisation of ERbeta and AR in mitochondria of the midpiece. Human Reproduction 20 3481-3487.

Stirone C, Duckles SP \& Krause DN 2003 Multiple forms of estrogen receptor-alpha in cerebral blood vessels: regulation by estrogen. American Journal of Physiology. Endocrinology and Metabolism 284 E184-E192.

Telleira CM, Zhong L, Deb S, Srivastava RK, Park KS, Sugino N, Park-Sarge OK \& Gibori G 1998 Differential expression of the estrogen receptors alpha and beta in the rat corpus luteum of pregnancy: regulation by prolactin and placental lactogens. Endocrinology 139 2432-2442.

Tetsuka M, Mihne M \& Hillier SG 1998 Expression of oestrogen receptor isoforms in relation to enzymes of oestrogen synthesis in rat ovary. Molecular and Cellular Endocrinology 25 29-35.

Tsai-Morris CH, Knox G, Luna S \& Dufau ML 1986 Acquisition of estradiolmediated regulatory mechanism of steroidogenesis in cultured fetal rat Leydig cells. Journal of Biological Chemistry 261 3471-3474.

Tyndale-Biscoe H \& Renfree M 1987 Reproductive Physiology of Marsupials, pp 476. Cambridge, Sydney, New York: Cambridge University Press.

Yang P, Wang J, Shen Y \& Roy SK 2004 Developmental expression of estrogen receptor (ER) alpha and ERbeta in the hamster ovary: regulation by follicle-stimulating hormone. Endocrinology 145 5757-5766.

Received 20 July 2009

First decision 4 September 2009

Revised manuscript received 1 November 2009

Accepted 21 December 2009 